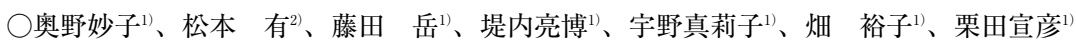

三井記念病院 耳鼻咽喉科 ${ }^{1)}$ 東京大学 医学部 耳鼻咽喉科 ${ }^{2}$

先天性真珠腫の診断技術の向上により、以前はステージが進んだものを手術する事が多かったが、最近は鼓室内に限局し て耳小骨連鎖にカリエスのないものを手術する事が多い。

伝音連鎖を保存して真珠腫のみ摘出したいと考える。しかも一期手術で終了できれば極めて患者負担も少ない。 内視鏡の導入は手術の低侵襲化に役立つ。また、顕微鏡と内視鏡を併用することは、手術の精度を高める事にもなる。 真珠腫の初発部位として知られる鼓膜張筋腱前後の処理、鼓室洞の処理、耳管鼓室口の処理は内視鏡を導入する事で確実 性がより高まった。乳突洞も観察口からの確認のみで乳突洞削開術に変える事もできる。

ビデオで症例の提示を行いながら、検証する。

当科における内視鏡下耳科手術の現状と課題

○小林泰輔、小森正博、兵頭政光

高知大学 医学部 耳鼻咽喉科

近年、中耳手術のすべてまたは大半を内視鏡下に行う内視鏡下耳科手術（Endoscopic Ear Surgery；EES）が行われるよ うになった。しかしEES は、片手操作となることやワーキングスペースが狭いなどの理由で、内視鏡下鼻内副鼻腔手術と 比べると未だ普及していない。本報告では2009年12月から 3 年間に当科で EES を行った 29 例、30耳を検討するとともに、 その課題について報告する。患者の年齢は 1 歳から 77 歳まで、平均 41.2 歳であった。疾患は先天性真珠腫、弛緩部型真珠 腫、緊張部型真珠腫、二次性真珠腫、耳小骨離断、外リンパ瘦、穿孔性中耳炎などである。EESで手術を開始して、顕微 鏡下手術に術中変更したのは、真珠腫除去のために器具が届かないため後壁を削開した 1 例、外耳道が狭く操作困難と判断 した鼓室内真珠腫（医原性疑い）1例、および真珠腫が大きく安全に摘出できないと判断した先天性真珠腫 1 例であった。 これらから EES の適応疾患と課題について考察を加える。

\title{
259 顕微鏡と内視鏡の相補的アプローチ
}

○松本 有 ${ }^{1}$ 、藤田 岳 ${ }^{1)}$ 、宇野真莉子 ${ }^{1)}$ 、畑 裕子 ${ }^{1)}$ 、奥野妙子 ${ }^{1)}$

三井記念病院 耳鼻咽喉科 ${ }^{1)}$ 、東京大学 医学部 耳鼻咽喉科 ${ }^{2)}$

先天性真珠腫に対する当科の治療方針としては、中下鼓室限局型に対しては経外耳道法、上鼓室および乳突洞進展症例に 対してはさらに後壁保存型乳突削開術を追加している。手術操作は双眼視と両手操作ができる利点から顕微鏡を主に用い、 内視鏡は前鼓室や鼓室洞など顕微鏡の死角となる部位の真珠腫遺残を確認するために使用している。

最近、内視鏡下耳科手術（EES）が注目を浴びている。EESの長所と短所、顕微鏡手術との使い分けについて議論が盛ん である。

本演題では鼓室から前鼓室、上鼓室、乳突洞まで大きく進展した先天性真珠腫症例を提示する。顕微鏡下に真珠腫を摘出 した後、内視鏡で前鼓室に真珠腫の遺残を確認した。開放した乳突洞経由で内視鏡を挿入し前鼓室を明視下に㧍き、外耳道 から弯曲針を挿入し遺残真珠腫を剥離摘出することが出来た。

以上の様に、乳突洞はそのまま内視鏡を挿入するルートとなるため、顕微鏡手術の死角を補いかつ EES の守備範囲の限 界を打ち破ることが可能である。手術ビデオを供覧する。

\section{0 当科で経験した Melatonic neuroectodermal tumor of infancy の 2 症例}

○高田生織、小川武則、加藤健吾、菊地俊晶、小澤大樹、鈴木貴博、日高浩史、大島猛史、小林俊光 東北大学 耳鼻咽喉頭頸部外科

Melatonic neuroectodermal tumor of infancy(MNTI) は、乳児に好発する神経原性腫瘍であり、1918年に Krompecherの 初報告以来447例の報告がある。まれな小児腫瘍であることに加え、再発率が高いことや悪性化の報告があることなど対応 に苦慮する腫瘍であると考えられる為、今回当科で経験した上顎発生 MNTI の 2 症例を報告する。症例 1 は生後 6 力月の 男児。腫瘍増大速度は軽微であり、精查後生後 9 カ月で腫瘍切除術を行い、再発なく術後15年を経過した。症例 2 は生後 2 カ月の女児。急速増大し、腫瘍出血も伴ったため、生後 3 カ月で上顎全摘術を行った。神経芽腫に準じた術後化学療法を追 加し、再発なく術後 6 力月を経過した。病理組織学的には、両症例ともメラニン色素を含んだ大型の上皮様細胞と小型の神 経芽細胞腫様細胞より構成されていたが、その構成比率は両症例で異なっており、臨床像の違いの一因と思われた。両症例 の経過を文献的考察と併せて報告する。 


\section{1 舌に生じた巨大乳児型血管周皮腫の 1 例}

○小澤大樹、小川武則、加藤健吾、菊地俊晶、且㴊 肇、高田生織、日高浩史、小林俊光

東北大学 医学部 耳鼻咽喉頭頸部外科

乳児型血管周皮腫は、生後 1 年以内に発生した血管周皮細胞の増生による腫瘍で頭頸部領域ではごくまれに頓粘膜や舌に 生じるが、今回胎児期に超音波検査抒よび MRI 検査にて巨大舌腫瘍と診断され、病理学的に乳児型血管周皮腫と診断され た症例を経験したので報告する。患児は妊娠30週時に口腔内腫瘍が認められ当院産婦人科へ紹介された。出生前の超音波検 查・MRI 検查から長径 $41 \mathrm{~mm}$ の舌血管腫が疑われ、妊娠 36 週に帝王切開にて分娩。臍帯切断前に気管内挿管が行われ、 NICU 入入院し、血管腫を念頭にステロイド投与や $\beta$ ブロッカー投与などの保存的治療が開始された。日齢17日目に気管切 開目的に当科紹介、気管切開施行。その後も保存的治療続けたが治療に抵抗性で、舌運動時の出血が続き、連日輸血を余儀 なくされる状態のため、生後 2 カ月で手術目的に当科へ再紹介。腫瘍血管の塞栓術を行った後、日齢75日目に両側外頸動脈 遮断、下顎骨非離断の上、口部舌半切術を行った。術後口蓋裂用乳頭で哺乳可能であり、術後化学療法後再発なく経過観察 中である。

\section{2 喉頭腺扁平上皮癌の 1 例}

○中村泰介、鴆根俊和、五味渕＼cjkstart寬、川口顕一朗、德留卓俊、藤居直和、下鑪裕子、三邊武幸

昭和大学藤が丘病院 耳鼻咽喉科

腺扁平上皮癌は、同一腫瘍組織内に腺管構造を有する腺癌と角化傾向や細胞間橋を有する扁平上皮癌の両方の癌組織が混 在する悪性腫瘍である。肺、食道、胃、子宮、大腸にも発生するが、どの部位においてもまれな悪性腫瘍とされている。特 に喉頭に発生する腺扁平上皮癌は非常に少なく、われわれが狩猟しえた限り本邦では15例の報告しかない。今回、われわれ は嗄声を主訴に受診した57歳の男性の喉頭に発生した腺扁平上皮癌（T3N2cM0）症例に対し、喉頭全摘出術、両側頸部郭 清術を行った。術後治療としてドセタキセル併用の化学放射線療法（CRT）を行い、良好な経過を得ることができた症例を 経験したので報告する。

\section{3 耳前部に発生した基底細胞腺癌の一例}

○宇野真莉子、堤内亮博、藤田 岳、畑＼cjkstart裕子、栗田宣彦、奥野妙子

三井記念病院 耳鼻咽喉科

基底細胞腺癌の大多数は高齢者の大唾液腺に発生するが、今回耳前部に発生した基底細胞腺癌を経験した。【症例】42歳 男性【主訴】左耳前部腫瘤【既往歴】なし【現病歴】2012年 5 月頃より左耳にイヤホンが入りにくいことを自覚していた。 軽度疼痛も出現してきたため、近医耳鼻咽喉科を受診。左外耳道入口部の腫瘤を指摘され、抗菌薬の内服や軟膏を塗布した が消退せず精査目的に当科加療目的に紹介となった。【身体所見】左耳前部に $2 \times 2 \mathrm{~cm}$ の弾性硬の腫瘤。軽度圧痛あり。左 外耳道は狭小化している。耳介周囲に瘦孔は認めない。【検查所見】 MRI：FN 左顎関節外側、外耳道上壁に及ぶ分葉状の 隔壁を持つ耳下腺とは離れる $3.4 \times 2.8 \times 2 \mathrm{~cm}$ の腫瘤性病変。A：class 2 。上皮性腫瘍と考える。【経過】全身麻酔下に左耳 前部腫瘍摘出術施行。腫瘍は耳珠軟骨と耳下腺の間に存在し耳下腺組織とは完全に離れていた。深部は結合織が硬いが明ら かな発生母地ははっきりしなかった。術後経過は良好で退院した。【病理検査】基底細胞腺癌本症例について若干の文献的 考察を加えて報告する。

\section{HPV 陽性を呈した両側扁桃癌の 1 例}

井出里香 ${ }^{1)}$ 、徳丸 裕2)、山川博毅1)

東京都立大塚病院 耳鼻咽喉科 ${ }^{11}$ 、独立行政法人国立病院機構 東京医療センター 耳鼻咽喉科 ${ }^{2}$

HPV 陽性の両側扁桃癌の報告例は少なく、昨年本邦でも症例報告がなされた。われわれも両側扁桃腺より HPV 感染陽性 で両側同時発生の扁桃癌を経験したので報告する。症例は58歳女性、喫煙歴・アルコール摂取の既往なし。左咽頭違和感に て近医受診。左扁桃腫瘍疑いにて当科紹介受診。初診時、左扁桃腫大を認めた。視診上、右扁桃腺に明らかな異常は認めな かった。頸部リンパ節腫脹なし。造影 MRI で両側扁桃腺は内部均一、造影後の増強効果にも不整像は認めなかった。PET CT で左扁桃腺に FDG 高集積を認めた。墨性リンパ腫との鑑別を含め、両側扁桃摘出術施行。病理検查にて中分化型扁平 上皮癌を認めた。margin 陰性。両側扁桃癌（pT1NoMo）と診断された。組織標本より HPV 検出（PCR 法）、HPV-16であ った。 